\title{
Contribution of Different Patient Information Sources to Create the Best Possible Medication History
}

\author{
Contribuição de Diferentes Fontes de Informação para \\ Obter a Melhor História Farmacoterapêutica Possível
}

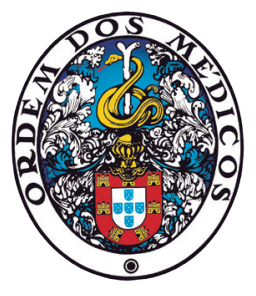

\author{
Joelizy OLIVEIRA ${ }^{1,2}$, Ana Cristina CABRAL ${ }^{2,3}$, Marta LAVRADOR ${ }^{2,3}$, Filipa A. COSTA ${ }^{4,5}$, Filipe Félix ALMEIDA ${ }^{6}$, \\ António MACEDO ${ }^{6}$, Carlos SARAIVA ${ }^{7}$, Margarida CASTEL-BRANCO ${ }^{2,3}$, Margarida CARAMONA², \\ Fernando FERNANDEZ-LLIMOS ${ }^{8}$, Isabel Vitória FIGUEIREDO $\rrbracket^{2,3}$ \\ Acta Med Port 2020 Jun;33(6):384-389 - https://doi.org/10.20344/amp.12082
}

\section{ABSTRACT}

Introduction: Obtaining the best possible medication history is the crucial step in medication reconciliation. Our aim was to evaluate the potential contributions of the main data sources available - patient/caregiver, hospital medical records, and shared electronic health records - to obtain an accurate 'best possible medication history'.

Material and Methods: An observational cross-sectional study was conducted. Adult patients taking at least one medicine were included. Patient interview was performed upon admission and this information was reconciled with hospital medical records and shared electronic health records, assessed retrospectively. Concordance between sources was assessed. In the shared electronic health records, information was collected for four time-periods: the preceding three, six, nine and 12-months. The proportion of omitted data between time-periods was analysed.

Results: A total of 148 patients were admitted, with a mean age of $54.6 \pm 16.3$ years. A total of 1639 medicines were retrieved. Only $29 \%$ were collected simultaneously in the three sources of information, $40 \%$ were only obtained in shared electronic health records and only $5 \%$ were obtained exclusively from patients. The total number of medicines gathered in shared electronic health records considering the different time frames were 778 (three-months), 1397 (six-months), 1748 (nine-months), and 1933 (12-months).

Discussion: The use of shared electronic health records provides data that were omitted in the other data sources available and retrieving the information at six months is the most efficient procedure to establish the basis of the best possible medication history.

Conclusion: Shared electronic health records should be the preferred source of information to supplement the patient or caregiver interview in order to increase the accuracy of best possible medication history of the patient, particularly if collected within the prior six months.

Keywords: Electronic Health Records; Medical History Taking; Medication Reconciliation

\section{RESUMO}

Introdução: A obtenção da melhor história farmacoterapêutica possível é uma etapa crucial da reconciliação da medicação. O objetivo foi avaliar as potenciais contribuições das principais fontes de informação disponíveis - doente/cuidador, Processo Único, Plataforma de Dados da Saúde e - para obter uma mais exacta melhor história farmacoterapêutica possível.

Material e Métodos: Foi realizado um estudo transversal observacional. Incluíram-se doentes adultos a tomar pelo menos um medicamento. A entrevista com o doente foi realizada na admissão e os dados do Processo Único e da Plataforma de Dados da Saúde recolhidos retrospetivamente. A concordância entre as fontes de informação foi avaliada. Na plataforma de dados da saúde, os dados foram recolhidos em quatro janelas temporais: os últimos três, seis, nove e 12- meses. Os dados omitidos entre os diferentes tempos foram analisados.

Resultados: Participaram 148 doentes, com uma idade média de 54,6 $\pm 16,3$ anos. Foram recolhidos 1639 medicamentos. Destes, $29 \%$ foram obtidos simultaneamente nas três fontes de informação, $40 \%$ foram obtidos apenas na Plataforma de Dados da Saúde e $5 \%$ foram obtidos exclusivamente a partir do doente. O número total de fármacos recolhidos na Plataforma de Dados da Saúde nos diferentes tempos foi 778 (três meses), 1397 (seis meses), 1748 (nove meses) e 1933 (12 meses).

Discussão: A consulta da Plataforma de Dados da Saúde permite obter dados omitidos nas outras fontes de informação e a recolha dos seis meses precedentes é o procedimento mais eficiente para constituir a base da melhor história farmacoterapêutica possível.

Conclusão: A Plataforma de Dados da Saúde deve ser a fonte de informação preferencial para complementar a entrevista do doente/ cuidador de forma a aumentar a exatidão da melhor história farmacoterapêutica possível, particularmente se a informação for recolhida em relação aos seis meses precedentes.

Palavras-chave: Anamnese; Reconciliação de Medicamentos; Registos Eletrónicos em Saúde

\section{INTRODUCTION}

Unsafe medication practices and medication errors are a leading cause of injury and avoidable harm in health care

systems across the world. The transition of care is a critical point in patient safety, increasing the risk of medication-

1. CAPES Foundation. Ministry of Education. Brasília. Brazil.

2. Departamento de Farmacologia e Cuidados Farmacêuticos. Faculdade de Farmácia. Universidade de Coimbra. Coimbra. Portugal.

3. Coimbra Institute for Clinical and Biomedical Research. Faculdade de Medicina. Universidade de Coimbra. Coimbra. Portugal.

4. Centro de Investigação Interdisciplinar Egas Moniz. Instituto Universitário Egas Moniz. Monte de Caparica. Portugal.

5. Grupo de Farmacoepidemiologia. Research Institute for Medicines - iMed. ULisboa. Universidade de Lisboa. Lisboa. Portugal.

6. Serviço de Psiquiatria. Centro Hospitalar e Universitário de Coimbra. Coimbra. Portugal.

7. Departamento de Psiquiatria. Faculdade de Medicina. Universidade de Coimbra. Coimbra. Portugal.

8. Laboratório de Farmacologia. Departamento de Ciências do Medicamento. Universidade do Porto. Porto. Portugal.

$\triangle$ Autor correspondente: Isabel Vitória Figueiredo. isabel.vitoria@netcabo.pt

Recebido: 20 de março de 2019 - Aceite: 04 de setembro de 2019 | Copyright @ Ordem dos Médicos 2020 
related incidents and preventable hospital admissions. ${ }^{1,2}$ Therefore, within the framework of the general plan for patient safety, in 2016, the Portuguese General Directorate of Health [Direção Geral da Saúde (DGS)] published a clinical practice guideline on medication reconciliation: Norma $018 / 2016 .^{3}$ The purpose of this guideline was to encourage the implementation of medication reconciliation - the formal process in which health care professionals partner with patients to ensure accurate and complete medication information transfer at interfaces of care. ${ }^{4}$ Medication reconciliation has demonstrated to improve safety and efficacy of medication prescribed between transitions of care, and reducing the risk of adverse events and consequently patients' medication-related morbidity and mortality. ${ }^{5-7}$

Medication reconciliation is a three-stage process. The first stage consists of gathering the best possible medication history (BPMH), which represents a compilation of different sources of information to obtain a list with the current medications (prescribed and non-prescribed) the patient was using before the transfer of interface of care; the second stage involves comparing the $\mathrm{BPMH}$ with a list of the current prescribed medication at the new interface of care, with the aim of identifying discrepancies; and finally in the third stage, these discrepancies are 'reconciled' with the medical team by differentiating intentional and unintentional ones. ${ }^{3}$ Thus, obtaining the BPMH is a crucial step to initiate the reconciliation process, since incomplete or inaccurate medication histories can increase the risk of medicationrelated errors and potential harm. ${ }^{8-11}$ Unresolved discrepancies may lead to discontinuation of clinically important medicines, or introduction of inappropriate or interacting medicines, which can potentially lead to hospital admissions, readmissions, or increase hospital stays. ${ }^{12}$

The World Health Organization (WHO) defends the use of a systematic process to obtain the $\mathrm{BPMH}$, considering the patient/caregiver as the main source of information. ${ }^{4}$ However, since patient's information may not always be reliable, other sources should be used to enhance the accuracy of medication history, such as hospital medical records (HMR) and shared electronic health records (SEHR). SEHRs are increasingly used worldwide and are leading to decreases in the number of medication errors and their role in the provision of health care is progressively recognized. ${ }^{13-16}$ In Portugal, in June 2012, an universal and centralised patient electronic health record platform [Plataforma de Dados da Saúde (PDS)] - was developed, enabling health professionals to have access to all the patient's clinical information, ${ }^{17}$ becoming one of the main sources to consider in medication reconciliation to obtain supplementary information to patient reports. The Portuguese PDS connects more than 370 health care instituitions, including all the public hospitals in Portugal, compiling their medical records into five central data bases.

Our aim was to evaluate the potential contributions of the three main data sources available in Portugal - patient/ caregiver, HMR, and SEHR (the Portuguese PDS) at different time frames - to obtain an accurate and reliable BPMH.

\section{MATERIAL AND METHODS}

An observational study was conducted in an acute care unit of the Center for Integrated Responsibility of Psychiatry and Mental Health, Coimbra University Hospital (CHUC) (January 2015 - February 2016). The study was approved by the Ethics Committees of Hospital University Center of Coimbra (CHUC-008-15) and University of Coimbra Faculty of Medicine (CE 109/2014). All participants signed an informed consent prior to their inclusion in the study.

\section{Population and setting}

This acute care unit consists of 27 beds in each of the two wards. The median length of hospitalization is 1.5 months, which means that the hospital unit receives on average 432 patients per year. Patients older than 18 years of age and taking at least one medicine at the moment of admission in the unit were invited to participate in the study. Exclusion criteria comprised pregnancy, patients controlled without medication, or patients unable to communicate by themselves or through a caregiver (due to cognitive impairment or language barriers).

\section{Data sources}

Data were obtained through three sources of information:

- Patient/caregiver - A standardized face-to-face interview was conducted by a trained pharmacist, using a data collection form, with the patient or the caregiver, within 72 hours after admission. When it was not possible to establish an interview with the patient due to serious mental impairment or other situations compromising the reliability of the information collected, the caregiver was invited. The main variables of interest collected were: medications currently taken, including prescription and non-prescription medicines, patient's medical conditions, allergies, and information about previous adverse drug reactions.

- Hospital medical records - HMR, the electronic medical record commonly used at the hospital, were used to collect information on the clinical information pertaining to the moment of admission at the mental unit, including admission diagnoses, and medicines prescribed at admission, and medicines identified during admission process as currently used (t0). This data source was assessed retrospectively.

- Shared electronic health record - SEHR (the Portuguese PDS) was accessed online from the acute care unit and was used to obtain the patient's medication history from the preceding year. This data source contains all the medicines prescribed to the patient, sequentially ordered, since 2012, which creates the need to define the best time cut-off to enable an efficient and feasible consultation in clinical practice. Information was collected for four timeperiods: the preceding three months ( $\mathrm{t} 3)$, six months (t6), nine months (t9), and 12-months (t12). 


\section{Data analysis}

Medicines were classified using the anatomical therapeutic chemical classification (ATC), with detail at the first level (ATC 1) and second level (ATC 2)..$^{18}$ Descriptive statistics were performed. To compare the four time cut-offs of the SEHR [the preceding three months (t3), six months (t6), nine months ( $\mathrm{t} 9$ ), and 12-months (t12)], information was assessed using the proportion of omitted data in each of these moments and then sub-analysed by the ATC group. The selection of the best retrospective cut-off was made based on two criteria: a) proportion of medicines lost when reducing the period of time analysed, and b) clinical relevance of the potential treatment omission and the potential substitutive effects of another prescribed medicine to the patient (e.g., the omission of sertraline was considered irrelevant if Mirtazapine was newly prescribed). Medicines omitted from six to nine months analysis and from nine to 12-months analysis were classified by analysing the medical records as: medicines for acute conditions, changes in prescribed medicine, dose treatment changes, end of treatment, or real omissions.

\section{RESULTS}

During the study period, 148 patients were admitted to the acute mental health unit, with a mean age of 54.6 years $(S D=16.3)$ and $75(50.7 \%)$ were females. Patient primary diagnoses are presented in Table 1.

\section{SEHR best retrospective time cut-off}

Table 2 provides the proportion of medicines omitted when considering one retrospective cut-off compared to the imediately longer period of time. A total of 778 medicines were retrieved considering the three months' time frame, 1397 medicines in the six months' time frame, 1748 medicines in the nine months' time frame, and 1933 medicines considering the 12-months' time frame of the SEHR. Comparing the three months cut-off versus the six months cutoff, the information obtained decreased $44.3 \%$, while the decreases were lower in the remaining cut-offs compari- sons $(20.1 \%$ t 6 vs t 9 , and $9.6 \%$ t9 vs t 12$)$. Table 3 presents the causes ascertained for medication omissions from six to nine months and from nine to 12-months analyses, classifying 55 as real omissions from six to nine months cut-off, and 19 from nine to 12 -months.

\section{Contribution of each information source to BPMH}

After aggregating the medicines obtained from the three sources (i.e., patient/caregiver, HMR, and SEHR at six months) a total of 1639 medicines were found. Only 476 medicines $(29 \%)$ were included in the three sources analysed. Ignoring one of these three sources to create the BPMH produced substantially different results. A total of $653(39.8 \%)$ medicines would be lost if the 6 -months retrospective cut-off of the SEHR is not used, eight $(0.5 \%)$ when the HMR is not used, and 77 (4.7\%) when patient/caregiver is not interviewed (Table 4). A total of 157 medicines omitted when using only the SEHR would be recuperated using any of the two other sources (Fig. 1).

\section{DISCUSSION}

In our study we evaluated the potential contributions of the three main available data sources (patient/caregiver, HMR, and SEHR) to obtain an accurate BPMH. Considering the large amount of information contained in SEHR, it was necessary to define the best time cut-off, especially because the literature is not consistent in establishing the best time frame to an SEHR retrospective consultation, with different authors suggesting different time cut-offs: Kalb et a/19 used the information of the previous 14 months; Lau et a ${ }^{\rho}$ used the information of the previous 12 months, while Prins et $a^{20}$ and Soler-Giner et $a^{R^{1}}$ used the information of the previous six months. In our study, nearly $45 \%$ of the medicines retrieved in the six month analysis would be ignored if we had retrieved information only from the three more recent months. Medication for the nervous system (group $\mathrm{N})$ presented the most similar profile when comparing the information at three and six months.

The number of medicines lost reduced to about $20 \%$

Table 1 - Patient primary diagnosis coded by the International Statistical Classification of Diseases and Related Health Problems $10^{\text {th }}$ Revision (ICD 10)

\begin{tabular}{lc}
\hline Patient primary diagnosis & $\mathbf{n}(\%)$ \\
\hline F30-F39 Mood [affective] disorders & $59(39.9)$ \\
F00-F09 Organic, including symptomatic, mental disorders & $42(28.4)$ \\
F10- F19 Mental and behavioral disorders due to psychoactive substance use & $15(10.1)$ \\
F50- F59 Behavioral syndromes associated with physiological disturbances and physical factors & $9(6.1)$ \\
F20-F29 Schizophrenia, schizotypal and delusional disorders & $8(5.4)$ \\
F60-F69 Disorders of adult personality and behavior & $6(4.1)$ \\
F70-F79 Mental retardation & $3(2.0)$ \\
F40-F48 Neurotic, stress-related and somatoform disorders & $2(1.4)$ \\
R40-R46 Symptoms and signs involving cognition, perception, emotional state and behavior & $2(1.4)$ \\
F80-F89 Disorders of psychological development & $1(0.7)$ \\
F99-F99 Unspecified mental disorder & $1(0.7)$ \\
\hline
\end{tabular}




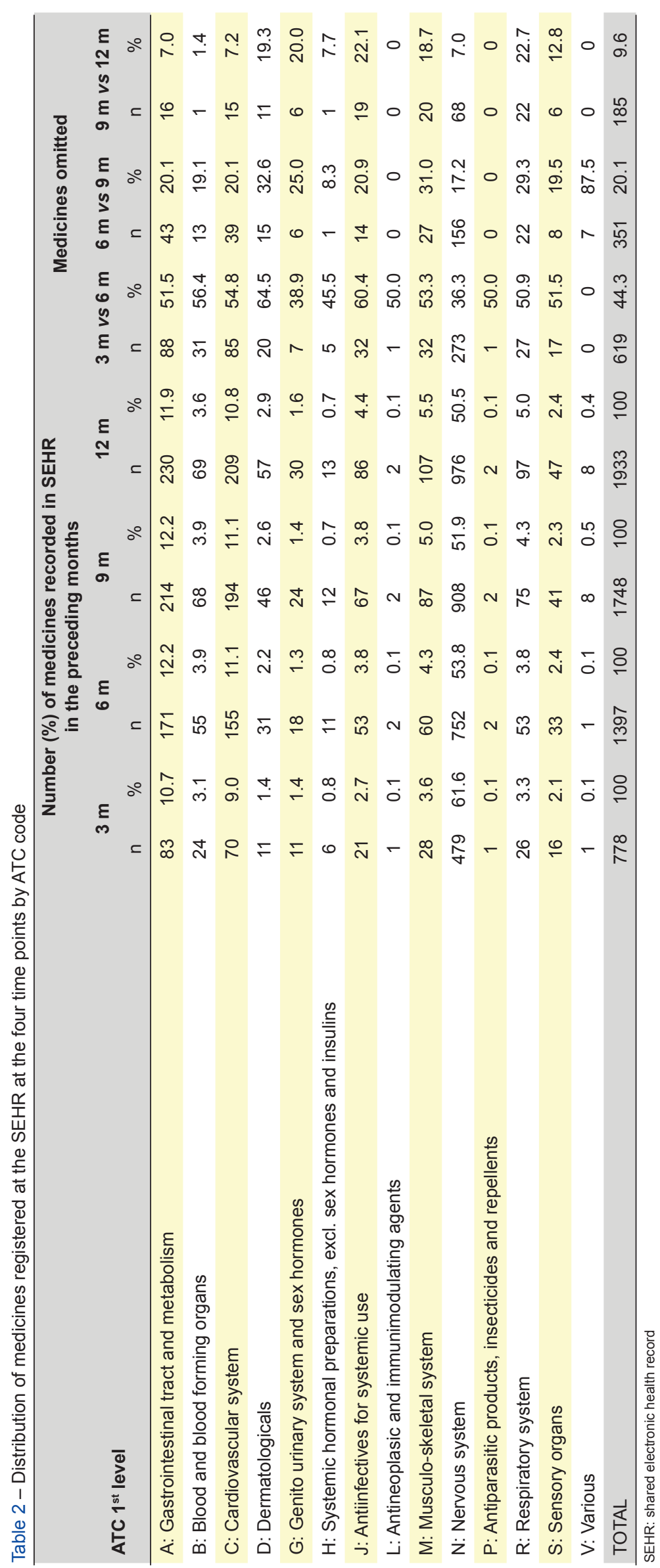

when comparing six and nine months and to nearly $10 \%$ when comparing nine and 12 -months analyses. This may be a consequence of the repeat prescribing system in Portugal, where a patient can obtain a prescription order with up to six months validity. Of these 351 medicines lost when comparing the six months and the nine month cutoffs, only $55(15.7 \%)$ were real omissions, with 15 medicines $(4.3 \%)$ considered as potentially serious omissions (anticoagulant, antiplatelet and antihypertensive medicines). These findings suggest that retrieving the information at six months is the most efficient procedure to constitute the basis of the $\mathrm{BPMH}$.

The use of SEHR to obtain BPMH allows not only identifying inaccurate doses and frequencies of prescribed medicines ${ }^{22}$ but also increases the accuracy of BPMH by providing data that were omitted in the other data sources available. In agreement with the $\mathrm{WHO}$ recommendations, ${ }^{4}$ we found that the SEHR should be supplemented with a face-to-face interview with the patient or the patient's caregiver. When supplementing the SEHR with the interview, the two drug classes more frequently added to the BPMH were the gastrointestinal tract drugs (ATC group A), followed by nervous and musculoskeletal system drugs (groups $\mathrm{N}$ and $M$, respectively). This way, the use of SEHR allows a reduction in the frequency of the main errors of the medication history identified at admission to hospital. ${ }^{23}$ Similar results were obtained in other studies made with National databases. ${ }^{24}$ Our study also demonstrated that the HMR does not add relevant data to that obtained with the other two information sources. In summary, the three sources present different strengths: while the SEHR revealed as the source providing more and more accurate information, patient or the patient's caregiver interview added information about nonprescription medicines and shared prescription medicines, ${ }^{25}$ and finally HMR complemented the BPMH with hospital-based prescriptions.

Although the SEHR demonstrated the highest potential to feed the BPMH, several limitations should be considered and overcome. The existence of different computerized prescribing systems among hospitals requires the use of information transfer processes to ensure that information is not lost when submitted to central repositories like the Portuguese Plataforma de Dados da Saúde-PDS. Technology-based solutions are being pointed as an important way to improve health care of patients with polypharmacy and multiple long-term conditions. ${ }^{26}$ Consequently, in the future, shared medication information repositories could simplify the reconciliation during the transitions of care, and increase patient safety. ${ }^{27}$ 
Table 3 - Causes of medicines omission between t 6 vs $\mathrm{t} 9$ and between $\mathrm{t} 9$ vs $\mathrm{t} 12$

\begin{tabular}{lcc}
\hline Omissions & t6 vs t9 & t9 vs t12 \\
\hline Types of omission & $\mathrm{n}(\%)$ & $\mathrm{n}(\%)$ \\
Medicines for acute conditions & $165(47.0)$ & $93(50.3)$ \\
Medicines switches (i.e., changes in prescribed medicines) & $93(26.5)$ & $56(30.3)$ \\
Changes in treatment dose & $24(6.8)$ & $10(5.4)$ \\
End of treatment & $14(4.0)$ & $7(3.8)$ \\
Real omissions & $55(15.7)$ & $19(10.3)$ \\
$\quad$ Potentially serious real omissions & $15(4.3)$ & $7(3.8)$ \\
TOTAL & $351(100)$ & $185(100)$ \\
\hline
\end{tabular}

Table 4 - Distribution of medication on the BPMH by ATC code and relative loss of information from each of the three sources considered

\begin{tabular}{|c|c|c|c|c|}
\hline ATC $1^{\text {st }}$ level & ВРMH & $\begin{array}{c}\text { Lost if SEHR } \\
\text { unused }\end{array}$ & $\begin{array}{c}\text { Lost if HMR } \\
\text { unused }\end{array}$ & $\begin{array}{l}\text { Lost if patient's } \\
\text { interview unused }\end{array}$ \\
\hline A: Gastrointestinal tract and metabolism & $227(13.8 \%)$ & $107(6.5 \%)$ & 0 & $32(1.9)$ \\
\hline B: Blood and blood forming organs & $70(4.3 \%)$ & $20(1.2 \%)$ & $1(0.1 \%)$ & $7(0.4 \%)$ \\
\hline C: Cardiovascular system & $189(11.5 \%)$ & $30(1.8 \%)$ & 0 & $9(0.5 \%)$ \\
\hline D: Dermatologicals & $35(2.1 \%)$ & $28(1.7 \%)$ & 0 & $1(0.1 \%)$ \\
\hline G: Genito urinary system and sex hormones & $20(1.2 \%)$ & $11(0.7 \%)$ & 0 & 0 \\
\hline H: Systemic hormonal preparations, excl. sex hormones and insulins & $11(0.7 \%)$ & $5(0.3 \%)$ & 0 & 0 \\
\hline J: Antiinfectives for systemic use & $57(3.5 \%)$ & $52(3.2 \%)$ & 0 & 0 \\
\hline L: Antineoplasic and immunimodulating agents & $2(0.1 \%)$ & 0 & 0 & 0 \\
\hline M: Musculo-skeletal system & $72(4.4 \%)$ & $40(2.4 \%)$ & 0 & $11(0.7 \%)$ \\
\hline $\mathrm{N}$ : Nervous system & $850(51.9 \%)$ & $281(17.1 \%)$ & $6(0.4 \%)$ & $16(0.9 \%)$ \\
\hline P: Antiparasitic products, insecticides and repellents & $3(0.2 \%)$ & $2(0.1 \%)$ & 0 & 0 \\
\hline $\mathrm{R}$ : Respiratory system & $60(3.7 \%)$ & $49(2.9 \%)$ & $1(0.1 \%)$ & 0 \\
\hline S: Sensory organs & $38(2.3 \%)$ & $26(1.6 \%)$ & 0 & 0 \\
\hline V: Various & $5(0.3 \%)$ & $2(0.1 \%)$ & 0 & $1(0.1 \%)$ \\
\hline TOTAL & $1639(100 \%)$ & $653(39.8 \%)$ & $8(0.5 \%)$ & $77(4.7 \%)$ \\
\hline
\end{tabular}

BPMH: best possible medication history; SEHR: shared electronic health record; HMR: hospital medical record

\section{Study limitations}

Our study has included patients admitted to an acute mental hospital unit. We cannot ensure that the results are similar to those that could be obtained with patients with other medical conditions or recruited in other hospital units in Portugal.

\section{CONCLUSION}

Electronical health records represent the most comprehensive source of information to create the patient's BPMH, although SEHR should be supplemented with a patient or patient's caregiver interview. The most efficient medication data retrieval process should consider a 6-month retrospective analysis of the SEHR.

\section{PROTECTION OF HUMANS AND ANIMALS}

The authors declare that the procedures were followed according to the regulations established by the Clinical Research and Ethics Committee and to the Helsinki Declaration of the World Medical Association.

\section{DATA CONFIDENTIALITY}

The authors declare having followed the protocols in

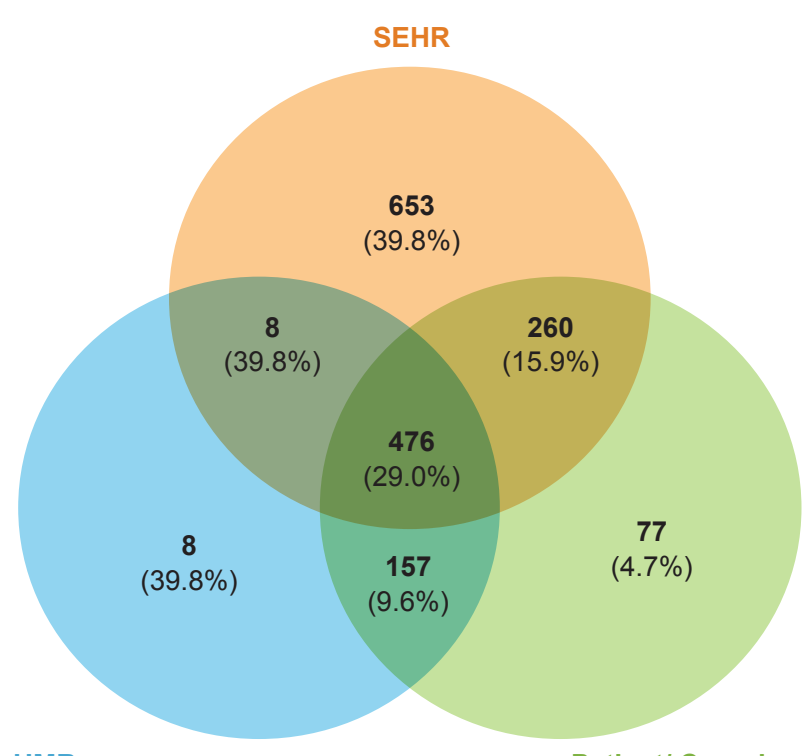

HMR

Figure 1 - Venn diagram exhibiting the contribution of each data source for the BPMH 
use at their working center regarding patients' data publication.

\section{CONFLICTS OF INTEREST}

The authors declare they have no conflict of interest.

\section{REFERENCES}

1. Gleason KM, McDaniel MR, Feinglass J, Baker DW, Lindquist L, Liss $D$, et al. Results of the Medications at Transitions and Clinical Handoffs (MATCH) study: an analysis of medication reconciliation errors and risk factors at hospital admission. J Gen Intern Med. 2010;25:441-7.

2. World Health Organization. Assuring medication accuracy at transitions of healthcare. Patient Safety Solution Volume 1, Solution 6. 2007. [accessed 2019 Jan 10]. Available from: http://www.who.int/ patientsafety/solutions/patientsafety/PS-Solution6.pdf.

3. Direcção Geral de Saúde. Norma 018/2016: Reconciliação da medicação. Lisboa: DGS; 2016.

4. World Health Organization. The High 5s Project standard operating protocol - assuring medication accuracy at transitions in care: medication reconciliation. Geneve: WHO; 2014

5. World Health Organization. Medication without harm: WHO's Third Global Patient Safety Challenge. [accessed 2018 May 23]. Available from: http://www.who.int/patientsafety/medication-safety/en/.

6. Franco-Donat M, Soler-Company E, Valverde-Mordt C, García-Muñoz S, Rocher-Milla A, Sangüesa-Nebot MJ. Medication reconciliation at hospital admission and discharge in an orthopedic surgery and traumatology department. Rev Esp Cir Ortop Traumatol. 2010;54:14955.

7. Mekonnen AB, McLachlan AJ, Brien JA. Pharmacy-led medication reconciliation programmes at hospital transitions: a systematic review and meta-analysis. J Clin Pharm Ther. 2016;41:128-44.

8. Johnston R, Saulnier L, Gould O. Best possible medication history in the emergency department: comparing pharmacy technicians and pharmacists. Can J Hosp Pharm. 2010;63:359-65.

9. Lau HS, Florax C, Porsius AJ, De Boer A. The completeness of medication histories in hospital medical records of patients admitted to general internal medicine wards. Br J Clin Pharmacol. 2000;49:597-603.

10. Slain D, Kincaid SE, Dunsworth TS. Discrepancies between home medications listed at hospital admission and reported medical conditions. Am J Geriatr Pharmacother. 2008;6:161-6.

11. Abuyassin $\mathrm{BH}$, Aljadhey $\mathrm{H}$, Al-Sultan M, Al-Rashed $\mathrm{S}$, Adam M, Bates DW. Accuracy of the medication history at admission to hospital in Saudi Arabia. Saudi Pharm J. 2011;19:263-7.

12. Tiihonen M, Nykanen I, Ahonen R, Hartikainen S. Discrepancies between in-home interviews and electronic medical records on regularly used drugs among home care clients. Pharmacoepidemiol Drug Saf. 2016;25:100-5.

13. Munck LK, Hansen KR, Molbak AG, Balle H, Kongsgren S. The use of shared medication record as part of medication reconciliation at hospital admission is feasible. Dan Med J. 2014;61:A4817.

14. Moore P, Armitage G, Wright J, Dobrzanski S, Ansari N, Hammond I, et al. Medicines reconciliation using a shared electronic health care record.

\section{FUNDING SOURCES}

This work had no financial support.
J Patient Saf. 2011;7:148-54

15. Bassi J, Lau F, Bardal S. Use of information technology in medication reconciliation: a scoping review. Ann Pharmacother. 2010;44:885-97.

16. Marien S, Krug B, Spinewine A. Electronic tools to support medication reconciliation: a systematic review. J Am Med Inform Assoc. 2017;24:227-40.

17. SPMS. PDS - Plataforma de Dados da Saúde. [accessed 2017 Jul 10] Available from: http://spms.min-saude.pt/2013/11/pds-plataforma-dedados-da-saude/.

18. World Health Organization. International Statistical Classification of Diseases and Related Health Problems 10th Revision (version 2010). [accessed 2017 JUL 10]. Available from: https://www.whocc.no/atc/ structure_and_principles.

19. Kalb K, Shalansky S, Legal M, Khan N, Ma I, Hunte G. Unintended medication discrepancies associated with reliance on prescription databases for medication reconciliation on admission to a general medical ward. Can J Hosp Pharm. 2009;62:284-9.

20. Prins MC, Drenth-van Maanen AC, Kok RM, Jansen PA. Use of a structured medication history to establish medication use at admission to an old age psychiatric clinic: a prospective observational study. CNS Drugs. 2013;27:963-9.

21. Soler-Giner E, Izuel-Rami M, Villar-Fernandez I, Real Campana JM, Carrera Lasfuentes P, Rabanaque Hernandez MJ. Calidad de la recogida de la medicación domiciliaria en urgencias: discrepancias en la conciliación. Farm Hosp. 2011;35:165-71.

22. Wang T, Biederman S. Enhance the accuracy of medication histories for the elderly by using an electronic medication checklist. Perspect Health Inf Manag. 2012;9:1-15.

23. Tam VC, Knowles SR, Cornish PL, Fine N, Marchesano R, Etchells EE. Frequency, type and clinical importance of medication history errors at admission to hospital: a systematic review. CMAJ. 2005;173:510-5.

24. Daupin J, Rosseaux G, Lebel D, Atkinson S, Bedard P, Bussieres JF. Comparison of information available in the medication profile of an electronic health record and the inpatient best possible medication history in a mother and child teaching hospital center. J Popul Ther Clin Pharmacol. 2016;23:e131-41.

25. Beyene K, Aspden T, Sheridan J. Prescription medicine sharing: exploring patients' beliefs and experiences. J Pharm Policy Pract. 2016;9:23.

26. Molokhia M, Majeed A. Current and future perspectives on the management of polypharmacy. BMC Fam Pract. 2017;18:70.

27. Bails D, Clayton K, Roy K, Cantor MN. Implementing online medication reconciliation at a large academic medical center. Jt Comm J Qual Patient Saf. 2008;34:499-508. 